\title{
Applying The Teacher Scholar Model In The School Of Business
}

John C. Gardner, University of New Orleans, USA

Carl B. McGowan, Jr., Norfolk State University, USA

Susan, E. Moeller, Eastern Michigan University, USA

\begin{abstract}
The teacher-scholar model was proposed in Boyer (1990) and defines four dimensions of scholarship: 1) discovery, 2) integration, 3) application, and 4) teaching. In this paper, we describe the characteristics of scholarship, the theory of the scholarship of teaching, the excellent teacher, and undergraduate research and scholarship. We then show how the teacher-scholar model is applied at one University for annual faculty evaluations.
\end{abstract}

Keywords: Teacher-Scholar Model, scholarship, teaching excellence, undergraduate research, faculty evaluation

\section{THE TEACHER-SCHOLAR MODEL}

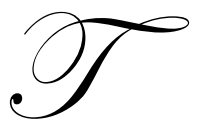

he Teacher-Scholar Model was expounded in a report from The Carnegie Foundation for the Advancement of Teaching by Ernest L. Boyer published in 1990. Boyer (1990) posits four forms of scholarship. The scholarship of discovery involves the creation of new knowledge. The scholarship of integration involves the synthesis of existing knowledge. The scholarship of application deals with using new and synthesized knowledge in problem solving. Thus, service would be the application of one's scholarship to problem solving at the School or University. The scholarship of teaching deals with bringing scholarship into the classroom.

The scholarship of discovery requires a scholar both to do original research and to publish original research. Faculty members must remain intellectually active throughout their careers and they must continue to publish original, peer, reviewed, work. The exact type of work to be produced in each field is determined by the nature of the field of study.

The scholarship of integration involves "serious, discipline work that seeks to integrate, draw together, and bring new insight to bear on original research." (Boyer, 1990, page 19) The scholarship of integration involves the integration of various research papers in the specific field and related fields into a synthesized whole. The scholarship of integration is interpretative and creates larger paradigms than originally posited and attempts to determine the meaning of the totality of the research. Textbook authors are examples of scholars of integration since writing a textbook requires a broad knowledge and understanding of the material of the field and an ability to present that material in as manner accessible to the new learner.

The scholarship of application involves the use of one's knowledge to solve specific problems both of society in general and in the School or University. Thus, faculty member joins committees where the committee's responsibility relates to the expertise of the faculty member. The scholarship of application effort "must be tied directly to one's special field of knowledge and relate to, and flow directly out of, this professional activity. Such service is serious, demanding work, requiring the rigor - and the accountability - traditionally associated with research activities." (Boyer, 1990, page 22)

The scholarship of teaching involves the process of conveying the knowledge of the instructor, acquired through the scholarship of discovery, the scholarship of integration, and the scholarship of application to the classroom. The teacher must be knowledgeable, well read, and engaged in the subject matter. The scholarship of 
teaching is also a process of learning as the scholar increase their understanding of the subject by the need to teach the material in a clear and understandable manner. Gibson, et. al. (2006) propose that one area of research for faculty is the scholarship of teaching and list a number of refereed journals that publish teaching and learning research. The authors categorize refereed journals as discipline based, curriculum based, academic process based, and administrative issue based.

In the School of Business at AACSB accredited institutions, the scholarship of discovery and the scholarship of integration are documented with refereed journal articles. The scholarship of application is documented by refereed journal articles and by service on School and University committees. The scholarship of teaching is documented with course material portfolios, student evaluations, and assessment processes as well as publishing in pedagogical based refereed journals.

\section{THE CHARACTERISTICS OF SCHOLARSHIP}

Glassick, Huber, and Maeroff (1997) define the characteristics of scholarship to be clear goals, adequate preparation, appropriate methods, significant results, effective presentation, and reflective critique. In writing a refereed journal article, one must begin with a clear goal often defined in the testable hypothesis being analyzed in the project. Adequate preparation would require that the scholar be familiar with the body of knowledge in the field that is applicable to the research hypothesis under consideration that is reflected in a literature review. Appropriate methodology refers to the research design being used to test the hypothesis defined in step one. Significant results refer to the importance of having empirical results that sufficiently support or reject the testable hypothesis. Effective presentation requires that the research results must be presented in a clear and concise fashion that is understandable to the referee. A reflective critique of the research requires that the author of the research be able to explain the implications of the research.

\section{THE THEORY OF THE SCHOLARSHIP OF TEACHING}

Bowden (2008) develops a model that links instructional theory and teaching strategies. Bowden defines three instructional theories: behaviorism, cognitivism, and constructivism. Behaviorism uses positive and negative feedback to reinforce behaviors in test subjects. Thus, the instructor rewards behaviors that increase learning and punish behaviors that decrease learning. Cognitivism fosters learning by weaving new information into the existing network of knowledge of the learner. Constructivism posits that learning is an active process and that learners must participate in the learning process to be successful. Thus, the learning process implementing all three approaches would involve using positive and negative feedback to promote desired actions or curtail undesired actions, present material as an extension of the existing knowledge base, and provide an environment of active learning.

Teaching strategies follow one of three approaches: discussion, lecture, and collaboration. Discussion is designed to promote critical thinking which validates existing information in the student knowledge base, to promote creative thinking to develop new and original information for the student, and to promote dialogical thinking designed to rationalize conflicting viewpoints and information. The lecture teaching model is designed to provide information to students from which students are encouraged to increase learning outside of the classroom. Collaboration is designed to allow small group learning. Student learning is increased because the group learns in a mutually supportive process.

Bowden argues that behavioralism and discussion are linked because behavioralism posits that behaviors can be changed and discussion changes behavior. The lecture method of teaching is linked to cognitivism in that the lecture method provides a large body of knowledge that the learner must rationalize in the existing knowledge base. Constructivism is an active learning process that is consistent with the collaborative teaching method which is an activity based problem solving process.

The instructor needs to match the teaching style with the instructional theories to optimize learning. That is, the instructor must use the teaching strategy (discussion, lecture, or collaboration) that best fits the instructional theory (behaviorism, cognitivism, or constructivism) for the student to maximize learning. 


\section{THE EXCELLENT TEACHER}

Bain (2004) defines excellent teachers as those who achieved remarkable success in helping their students learn in ways that made a sustained, substantial, and positive influence on how ... students think, act, and feel." Excellent teachers are active and accomplished scholars, approach teaching as a serious intellectual endeavor, expect "more" from students, create a "natural critical learning environment, trust students, and use a systematic program of assessment of student learning. Excellent teachers have learned how to foster learning, do not blame students for difficulties, and have a strong sense of commitment to the academic community.

Gibson, et al., (2006) suggest that an area of research for faculty is the "scholarship of teaching and learning." Faculty can write pedagogical articles, discipline based articles, curriculum based articles, academic issues articles, and administrative based articles. The authors list articles and journals in which articles might be published. Yerigan (2008) posits that active learning is the most effective learning, i. e., students retain the most information when they teach (present) material. "Most educators have heard that people generally remember $10 \%$ of what they read, $20 \%$ of what they hear, $30 \%$ of what they see, $50 \%$ of what they hear and see, and $90 \%$ of what they teach." Thus, students will retain more of a topic on which they have made a presentation, i.e., taught.

\section{UNDERGRADUATE RESEARCH AND SCHOLARSHIP}

Shea, Sherer, and Nenart (2009) analyze the use of undergraduate research in schools of business for AACSB schools in the United States (91), AACSB schools outside of the United States (15), and schools listed in the U.S. News and World report's list of top programs in "Undergraduate/Creative Projects for 2007 (34). The authors rank schools on a six point scale with zero indicating "No evidence of undergraduate research activities." And a rating of five indicates "An active, integrated undergraduate research program is in place and also includes innovative features." The authors find that undergraduate research at schools with higher ratings (four or five) are large, have programs that started with a summer program, concentrate in the sciences, have an annual conference, have a website, and participate in the National Council on Undergraduate Research. The US News group has a rating of 4.1 for the school overall and 1.4 at business schools. The US AACSB group has a rating of 2.2 for the school overall and 0.9 at business schools. The international AACSB group has a rating of 1.1 for the school overall and 0.6 at business schools. The authors conclude that although undergraduate research programs have value for the student, the faculty, and the institution, business schools do not provide these opportunities.

Shea, et. al. discuss undergraduate research using a model that integrates teaching, research, learning, scholarship, and knowledge using a model from Brown (2006). The authors posit that students benefit from undergraduate research by improved research skills, communication skills, management skills, professional development.

Jalbert (2008) discusses experiences with a six year program of research with under-graduate students that have lead to ten refereed journal articles, four awards, eight refereed proceedings, and eight presentations. Jalbert discusses process of selecting the student for undergraduate research that begins with a pre-screening to insure that the students have the ability, the time, the interest, and the willingness to finish the project once started. Students are interviewed and the process is settled with respect to the project and the grading of the project. The experience was rewarding to Jalbert and other participants in the program. Further, Elgren (2006) states that "Collaborative research speaks to some of our most fundamental educational objectives by providing a personalized education, exemplifying engaged pedagogy, and promoting students' intellectual independence and maturation."

Bartkus (2008) proposes a framework for student research experience that is organized as a think tank with faculty as 'managing partners' with students functioning as associates. Bartkus suggests that undergraduate research experiences should be meaningful, should prepare students for graduate study, should involve presentations, should involve students in research symposiums, and should require students to participate in organization that promote undergraduate research. Student participants should have a high grade point average and should have merit and potential. Enticing faculty to participate is challenging as is finding meaningful projects for undergraduate research. 


\section{EVALUATING THE TEACHER-SCHOLAR}

The School of Business NSU Teaching Faculty Evaluation has four components: Teaching, Scholarly Activity, Professional Development and Service, and University Service. Community Service can be added at the faculty member's discretion. Currently, teaching is based on a portfolio that includes the course syllabus, all examinations, and handouts used in the class. Faculty teaching evaluation further includes teaching evaluations. Faculty members are required to conduct assessment of learning analysis but this is not a part of the evaluation process. To achieve the full four points available for Scholarly Activity each year the faculty member must publish at least one refereed journal article. Fewer points are offered for refereed proceedings and presentations at professional conferences. University service points are awarded for serving on committees at the school or university level. Although full points are awarded for serving on one committee, most faculty members serve on more than one committee. Teaching evaluation is based on a formula that combines the teaching portfolio and student evaluations.

In conclusion, the Teacher-Scholar model as defined by Boyer (1990) is being used as the basis for faculty member evaluation at the NSU School of Business. Scholarly Activity (discovery and integration) is measured by refereed articles, University Service (application) is measured by committee service at the university, and teaching is measured by the faculty member's teaching portfolio, student evaluations, and assessment processes. The TeacherScholar Model is not a one time application but is an on going process. Currently, the Research Committee for the School of Business is looking to expand the use of Cooperative Learning and Undergraduate Research Projects to expand and improve teaching and the use of the teacher-Scholar Model.

\section{SUMMARY AND CONCLUSIONS}

The teacher-scholar model was proposed in Boyer (1990) and defines four dimensions of scholarship 1) discovery, 2) integration, 3) application, and 4) teaching. Glassick, Huber, and Maeroff (1997) define the six characteristics of scholarship as being clear goals, adequate preparation, appropriate methods, significant results, effective presentation, and reflective critique. Bowden (2008) links instructional theory and teaching strategies to optimize learning. The instructor uses the teaching strategy (discussion, lecture, or collaboration) that best fits the instructional theory (behaviorism, cognitivism, or constructivism) for the student to maximize learning. Bain (2004) defines the excellent teacher as a teacher who is an active researcher, who treats teaching as a serious endeavor, and who uses a systematic approach to assessing student learning. Numerous authors find that working with undergraduate students on research promotes student learning and faculty research.

Norfolk State University has an annual evaluation process for all teaching faculty that covers four dimensions. First, faculty teaching is evaluated with two measures using student evaluations for one measure and using the teaching portfolio that includes syllabi, tests, and handout as a second measure. The second dimension of teaching faculty evaluations is service measured by faculty participation in committees at the department, school and university level. The third dimension of evaluation is professional activity to include publishing in refereed journals, proceedings, and presentations at professional conferences. Both discovery and integration research are treated the same. In the context of the teacher-scholar model, the annual faculty evaluation at Norfolk State University mirrors the four aspects of scholarship discussed in Boyer (1990).

\section{AUTHOR INFORMATION}

John C. Gardner is the KPMG Professor of Accounting and Director of the Global Entrepreneurship Initiative in the Department of Accounting at the University of New Orleans. He earned his undergraduate degree in accounting from SUNY at Albany, and MBA and Ph.D. degrees in finance from Michigan State University. Dr. Gardner has published in leading accounting, finance and management science journals including The Accounting Review, Journal of Accounting Research, Contemporary Accounting Research, Accounting, Organizations and Society, Journal of Financial and Quantitative Analysis and Decision Sciences. His research interests include multi-national corporation financial management, capital structure, and financial and forensic accounting. 
Carl B. McGowan, Jr., PhD, CFA is a Professor of Finance at Norfolk State University. Dr. McGowan has a BA in International Relations (Syracuse), an MBA in Finance (Eastern Michigan), and a $\mathrm{PhD}$ in Business Administration (Finance) from Michigan State. From 2003 to 2004, he held the RHB Bank Distinguished Chair in Finance at the Universiti Kebangsaan Malaysia and has taught in Cost Rica, Malaysia, Moscow, Saudi Arabia, and The UAE. Professor McGowan has published in numerous journals including Applied Financial Economics, Decision Science, Financial Practice and Education, The Financial Review, International Business and Economics Research Journal, The Journal of Applied Business Research, The Journal of Current Research in Global Business, The Journal of Diversity Management, The Journal of Global Business, The Journal of Real Estate Research, Managerial Finance, Managing Global Transitions, The Southwestern Economic Review, and Urban Studies.

Susan Moeller is a Professor of Finance at Eastern Michigan University. She teaches in the area of corporate finance and has published in a variety of journals including Managing Global Transitions, Journal of Global Business, and Business Journal.

\section{REFERENCES}

1. Bain, Ken. "What the Best College Teachers Do," Harvard University Press, Cambridge, 2004.

2. Bartkus, Kenneth R. "The Research Group Framework: A Strategic Approach to Undergraduate Research Experiences in Colleges and Schools of Business," Decision Line, October 2008, pp: 7-9.

3. Bowden, Randall. "Linking Premise to Practice: An Instructional Theory-Strategy Model Approach," Journal of College Teaching \& Learning," Volume 5, Number 3, March 2008, pp: 69-76.

4. Boyer, Ernest L. "Scholarship Reconsidered: Priorities of the Professorate," The Carnegie Foundation for the Advancement of Teaching, Jossey-Bass (a Wiley imprint), 1990.

5. Elgren, Tim. "Undergraduate Research Experience: Synergies between Scholarship and Teaching," Peer Review, Winter 2006, pp. 4-7.

6. Gibson, Jane Whitney, Charles W. Blackwell, Regina A. Greenwood, and Gail Purvis. "Research for Teaching and Learning," Journal of College Teaching \& Learning, November 2006, Volume 3, Number 11, pp. 53-57.

7. Glassick, Charles E., Mary Taylor Huber, and Gene I. Maeroff. "Scholarship Assessed: Evaluation of the Professoriate," AN Ernest L. Boyer Project of Carnegie Foundation for the Advancement of Teaching, Jossey-Bass (a Wiley imprint), 1997.

8. Jalbert, Terrance. "Experiences in publishing peer-reviewed research with undergraduate accounting and finance students," Journal of Accounting Education, Volume 26, 2008, pp: 104-117.

9. Shea, Timothy, Pamela D. Sherer, and Tara Nenart. "Undergraduate Research in Business Schools: An Underutilized Opportunity for Students and Faculty," Journal of the Academy of Business Education," Fall 2009, Volume 10, pp. 126-144.

10. Yerigan, Tanya. "Getting Active in the Classroom," Journal of College Teaching \& Learning, June 2008, Volume 5, Number 6, pp. 19-24. 
NOTES 